\title{
PENGARUH MODEL PEMBELAJARAN KOOPERATIF DAN KECERDASAN GANDA TERHADAP HASIL BELAJAR EKONOMI SISWA SMA NEGERI 1 MEDANG DERAS KABUPATEN BATU BARA
}

\author{
Rima Zakirah Sirai ${ }^{1}$, Julaga Situmorang ${ }^{2}$ \\ Pascasarjana Universitas Negeri medan ${ }^{1,2}$ \\ rima_zakiah@yahoo.com ${ }^{l}$
}

\begin{abstract}
Abstrak: Tujuan penelitian ini adalah: (1) Untuk mengetahui perbedaan hasil belajar ekonomi melalui pembelajaran kooperatif jigsaw berbeda dari siswa yang diajar dengan pembelajaran kooperatif Think Pair Share; (2) Untuk mengetahui perbedaan hasil belajar ekonomi antara siswa yang memiliki kecerdasan interpersonal dengan siswa yang memiliki kecerdasan intrapersonal; (3) Untuk mengetahui interaksi antara model pembelajaran kooperatif dengan kecerdasan ganda yaitu kecerdasan interpersonal dan intrapersonal dalam mempengaruhi hasil belajar ekonomi siswa kelas X SMA Negeri 1 Medang Deras. Hasil penelitian ini menunjukkan bahwa: (1) siswa yang diajarkan dengan pembelajaran kooperatif jigsaw lebih tinggi dari diajarkan dengan pembelajaran kooperatif TPS; (2) siswa yang memiliki kecerdasan Interpersonal lebih tinggi dari yang memiliki kecerdasan Intrapersonal; (3) Terdapat Interaksi antara model pembelajaran kooperatif dengan kecerdasan ganda (interpersonal dan intrapersonal) dalam mempengaruhi hasil belajar Ekonomi
\end{abstract}

Kata Kunci: model pembelajaran kooperatif, kecerdasan ganda, belajar ekonomi

\begin{abstract}
The purpose of this study are: (1) To determine differences in learning outcomes of the economy through different jigsaw cooperative learning of students taught by cooperative learning Think Pair Share; (2) To know the difference between the results of the economic study of students who have interpersonal intelligence with students who have intrapersonal intelligence; (3) To understand the interaction between cooperative learning model with multiple intelligences namely interpersonal and intrapersonal intelligence in influencing learning outcomes of economic class $X$ SMA Negeri 1 Medang Deras. The results of this study indicate that: (1) students taught by cooperative learning jigsaw higher than taught by cooperative learning TPS; (2) students who have Interpersonal intelligence is higher than that have intrapersonal intelligence; (3) There is interaction between cooperative learning model with multiple intelligence (interpersonal and intrapersonal) in influencing learning outcomes Economy
\end{abstract}

Keywords: cooperative learning, multiple intelligences, learning economics

\section{PENDAHULUAN}

Ekonomi merupakan salah satu cabang IPS yang memberikan pengetahuan tentang bagaimana pola kehidupan dengan konsep ilmu ekonomi dan merupakan usaha yang dilakukan secara terencana dan berkesinambungan dalam rangka mengembangkan kemampuan siswa untuk memahami fakta, konsep dan generalisasi tentang perilaku ekonomis dan kesejahteraan serta menerapkan untuk berperilaku yang rasional dan manusiawi dalam memanfaatkan sumberdaya ekonomi, menumbuhkan jiwa, sikap dan perilaku kewirausahaan, menganalisis sistem informasi keuangan lembaga ekonomi, terampil dalam praktek usaha ekonomi sendiri, berpikir logis, kritis dan lateral dengan memperhitungkan potensi dan peluang menghadapi kemungkinan, menunjukkan motivasi dalam belajar, dan meningkatkan kepercayaan diri, mampu bekerja mandiri, dan bekerjasama dengan orang lain.

Kecerdasan adalah kapasitas seseorang untuk menyelesaikan masalah-masalah dan membuat caranya dalam konteks yang beragam, dan wajar. Gardner (1999) menyebutkan ada Sembilan jenis kecerdasan yang dimiliki oleh setiap individu yaitu (1) kecerdasan ruang dan visual, (2) kecerdasan lisan atau bahasa, (3) kecerdasan matematis dan logis, (4) kecerdasan fisik dann gerak, (5) kecerdasan musik dan ritme, (6) kecerdasan interpersonal, (7) kecerdasan intrapersonal, (8) kecerdasan 
naturalis, dan (9) kecerdasan ekstensialis. Hal yang perlu diperhatikan adalah bahwa setiap individu memiliki kesembilan kecerdasan tersebut, setiap individu dapat mengembangkan kecerdasan tadi sampai mencapai suatu tingkat yang memadai, kecerdasan bekerja satu sama lain secara kompleks, dan dalam tiap kecerdasan ada berbagai cara untuk menumbuhkan salah satu aspeknya.

Belajar merupakan perubahan tingkah laku. Belajar adalah proses perubahan perilaku berkat pengalaman dan pelatihan. Artinya, tujuan kegiatan belajar ialah perubahan tingkah laku, baik yang menyangkut pengetahuan, keterampilan, sikap, bahkan meliputi segenap aspek pribadi. (Sabri, 2007 : 19). Belajar adalah suatu proses yang kompleks yang terjadi pada semua orang dan berlangsung seumur hidup, sejak manusia masih bayi hingga ke liang lahat. Seseorang telah belajar ditandai dengan sesuatu adalah adanya perubahan tingkah laku dalam dirinya. Perubahan tingkah laku tersebut tidak saja menyangkut perubahan yang bersifat pengetahuan (kognitif) dan keterampilan (psikomotor) tetapi juga menyangkut nilai dan sikap (afektif).

Sedangkan menurut Gagne, Briggs \& Wager dalam Salma (2008 : 24) menyatakan bahwa proses belajar seseorang dapat dipengaruhi oleh faktor internal peserta didik itu sendiri dan faktor eksternal, yaitu pengaturan kondisi belajar. Proses belajar terjadi karena sinergi memori jangka pendek dan jangka panjang diaktifkan melalui penciptaan faktor eksternal, yaitu pembelajaran atau lingkungan belajar. Melalui inderanya, peserta didik dapat menyerap materi secara berbeda. Pengajar mengarahkan agar pemrosesan informasi untuk memori jangka panjang dapat berlangsung lancar.

Romiszwoski dalam Yenice Rahmah (2008 : 12) mengemukakan bahwa hasil belajar merupakan keluaran (output) dari suatu sistem pemrosesan masukan (inputs). Masukan dari sistem tersebut bermacam-macam informasi sedangkan keluarannya adalah perbuatan atau kinerja (performance). Menurut Romiszoski perbuatan merupakan petunjuk bahwa proses belajar telah terjadi dan hasil belajar dikelompokkan dalam dua macam yaitu pengetahuan dan keterampilan. Pengetahuan terdiri dari empat kategori yaitu : (1) pengetahuan tentang fakta, (2) pengetahuan tentang konsep, (3) pengetahuan tentang prinsip, dan (4) pengetahuan tentang prosedur dan keterampilan berinteraksi. Menurut Reigeluth dalam Helminaria Hutabarat (2008:6), hasil pembelajaran secara umum dapat dikategorisasi menjadi tiga indikator, yaitu (a) efektifitas pembelajaran, yang biasanya diukur dari tingkat keberhasilan (prestasi) mahasiswa dari berbagai sudut, (b) efisiensi pembelajaran, yang biasanya diukur dari waktu belajar dan biaya pembelajaran, dan (c) daya tangkap pembelajaran yang selalu diukur dari tendensi mahasiswa ingin belajar secara terus menerus. Perubahan sebagai hasil proses belajar dapat ditunjukkan dalam berbagai bentuk, seperti kecakapan, kebiasaan, sikap, pengertian, pengetahuan atau upresiasi (penerima atau penghargaan). Perubahan tersebut dapat meliputi keadaan dirinya, pengetahuan atau perbuatannya. (Sabri, 2007 : 32).

Pada tingkat yang amat umum sekali, hasil pembelajaran dapat diklasifikasikan menjadi 3 (tiga), yaitu (1) keefektifan (effectiveness), (2) efisiensi (efficiency), (3) daya tarik (appeal). (Uno, 2008:21). Hasil belajar merupakan hasil yang menunjukkan kemampuan seseorang siswa dalam menguasai bahan pelajarannya. Hasil belajar dapat diuji melalui test sehingga dapat digunakan untuk mengetahui keefektifan pengajaran dan keberhasilan siswa atau guru dalam proses belajar mengajar. Untuk mengetahui sampai di mana siswa berhasil dalam belajar dapat dilakukan dengan memberikan evaluasi yaitu berupa tes hasil belajar. Evaluasi berfungsi untuk mengetahui kemajuan dan perkembangan serta keberhasilan siswa setelah mengalami atau melakukan kegiatan belajar selama jangka waktu tertentu (Purwanto, 2001:5). Selanjutnya Sudjana \& Rivai (2003:148) menjelaskan bahwa penilaian hasil belajar bertujuan melihat kemajuan belajar para siswa dalam hal penguasaan materi pembelajaran yang telah dipelajarinya sesuai dengan tujuan-tujuan yang telah ditetapkan.

Menurut Samuelson (dalam Rosyidi, 2005:9) Ekonomi adalah studi mengenai caracara yang ditempuh oleh masyarakat untuk menggunakan sumber daya yang langka guna memproduksi komoditas atau barang-barang yang bermanfaat serta mendistribusikannya kepada semua orang. Sejalan dengan Samuelson (dalam Rosyidi, 2005:8) menjelaskan pengertian pertama dari ekonomi yaitu bahwa ekonomi adalah salah satu cabang ilmu penegtahuan yang berdaya upaya untuk 
memberikan pengetahuan dan pengertian tentang gejala-gejala masyarakat yang timbul karena perbuatan manusia dalam usahanya untuk memenuhi kebutuhan hidupnya atau untuk mencapai kemakmuran.

Samuelson (dalam Rosyidi, 2005:10) menjelaskan bahwa terdapat tiga masalah fundamental dalam ekonomi atau sering disebut The Three Fundamental and Interdependent Economic Problem yaitu : (1) What commodities shall be produced and in what quantities? Barang-barang apa yang akan dibuat dan seberapa banyak? Artinya berapa banyak serta manakah dari barang-barang atau jasa-jasa yang akan dipilih untuk diproduksi, (2) How shall goods be produced? Dengan cara apa barang-barang tersebut dihasilkan? Artinya siapa yang akan mengerjakan dan dengan sumber-sumber apa serta dengan system teknologi yang bagaimanakah barang-barang tersebut dihasilkan, dan (3) For whom shall goods be produced? Untuk siapakah barangbarang yang dihasilkan itu nantinya? Artinya siapakah yang akan dan harus menikmati serta memperoleh manfaat dari hasil barang-barang tersebut.

pembelajaran, hasi belajar memberikan gambaran tentang kemajuan belajar siswa atau sebaliknya dan membantu seorang guru untuk merencanakan langkah baru untuk mencapai hasil belajar yang lebih baik. Untuk mengetahui hasil belajar tersebut, maka seorang guru harus mengadakan evaluasi. Davies (dalam Dimyati \& Mudjiono, 2006:190) mengemukakan bahwa evaluasi merupakan proses sederhana memberikan/ menetapkan nilai kepada sejumlah tujuan, kegiatan, keputusan, unjuk kerja, proses, orang, objek, dan masih banyak yang lain. Sedangkan Wand \& Brown (dalam Dimyati \& Mudjiono, 2006:191) mengemukakan bahwa evaluasi merupakan suatu proses menentukan nilai dari sesuatu. Jika proses yang dilakukan itu adalah proses belajar, berarti nilai yang ditentukan adalah nilai belajar yang kemudian disebut hasil belajar.

Winata Putra (2001:120) menyatakan model diartikan sebagai kerangka konseptual yang digunakan sebagai pedoman dalam melakukan sesuatu kegiatan. Komaruddin dalam Sagala (2007:175) menyatakan model dapat dipahami sebagai : (1) suatu tipe atau desain, (2) suatu deskripsi atau analogi yang dipergunakan untuk membantu proses visualisasi sesuatu yang tidak dapat dengan langsung diamati, (3) suatu sistem asumsiasumsi, data-data, dan inferensi-inferensi yang dipakai untuk menggambarkan secara sistematis suatu objek atau peristiwa, (4) suatu desain yang sederhana dari suatu sistem kerja, atau suatu terjemahan realitasyang disederhanakan, (5) suatu deskripsi dari suatu sistem yang mungkin atau imajiner, dan (6) penyajian yang diperkecil agar dapat menjelaskan dan menunjukkan sifat bentuk aslinya.

Joyce dan Weil (1992:4) menyatakan "A model of teaching is a plan or patten that we can use to design face to face teaching in classroom or tutorial settings and to shape instructional materials-including books, films, tapes, and computer-mediated programs and curriculums". Dari kutipan ini model pembelajaran adalah suatu perencanaan atau pola yang digunakan sebagai pedoman dalam merencanakan pembelajaran di kelas atau pembelajaran dalam tutorial dan untuk menentukan perangkat-perangkat pembelajaran termasuk di dalamnya buku-buku, film, tape, program media komputer, dan kurikulum.

Menurut Slavin dalam Isjoni (2007:12), cooperative learning adalah suatu model pembelajaran dimana siswa belajar dan bekerja dalam kelompok-kelompok kecil secara kolaboratif yang anggota-anggotanya 4-6 orang dengan struktur kelompok heterogen. Sedangkan Sunal dan Hans (2000) mengemukakan pembelajaran kooperatif merupakan suatu cara pendekatan atau serangkaian strategi yang khusus dirancang untuk member dorongan kepada peserta didik agar bekerjasama selama proses pembelajaran. Selanjutnya Stahl (1994) menyatakan cooperative learning dapat meningkatkan belajar siswa lebih baik dan meningkatkan sikap tolong menolong dalam perilaku sosial. Pembelajaran kooperatif merupakan suatu pendekatan dalam proses pembelajaran yang membutuhkan partisipasi dan kerja sama kelompok. Pembelajaran kooperatif menekankan aktivitas siswa dalam belajar kelompok, dan memanfaatkan bantuan siswa lain untuk meningkatkan pemahaman, dan penguasaan bahan pelajaran.

Menurut Kunandar (2007 : 359) model pembelajaran kooperatif adalah pembelajaran yang secara sadar dan sengaja mengembangkan interaksi yang saling asuh antarsiswa untuk menghindari ketersinggungan dan kesalahpahaman yang dapat menimbulkan permusuhan.Menurut Thomson, et.al. (1995) 
seperti yang dikutip oleh Aqib dan Rohmanto (2007) bahwa pembelajaran kooperatif turut menambah unsure-unsur interaksi social khususnya pada pembelajaran ekonomi. Di dalam pembelajaran kooperatif, siswa belajar bersama dalam kelompok-kelompok kecil dan saling membantu satu sama lain. Kelas disusun dalam kelompok-kelompok kecil dan saling membantu satu sama lain. Kelas disusun dalam kelompok-kelompok yang terdiri dari 4-5 orang siswa dengan kemampuan, jenis kelamin, dan suku yang berbeda. Lebih lanjut Slavin (1986) menyatakan bahwa hal ini bermanfaat untuk melatih siswa menerima pendapat dan bekerja sama dengan teman yang berbeda latar belakang baik tingkat kemampuan belajar atau kecerdasan.

Tujuan utama dalam penerapan model belajar mengajar pembelajaran kooperatif adalah agar peserta didik dapat belajar secara berkelompok bersama teman-temannya dengan cara saling menghargai pendapat dan memberikan kesempatan kepada orang lain untuk mengemukakan gagasannya dengan menyampaikan pendapat mereka secara berkelompok. (Isjoni, 2007:21)
Tipe Think Pair Share (TPS) tumbuh dari penelitian pembelajaran kooperatif. Pembelajaran kooperatif TPS mula-mula dikembangkan oleh Frank Lymanm, dkk dari Universitas Maryland pada tahun 1985. Tipe TPS mmerupakan salah satu variasi dalam model pembelajaran kooperatif dari pendekatan struktur. Pembelajaran kooperatif TPS menekankan pada pola kerjasama siswa dalam membantu kelompok kecil dan lebih menginginkan penghargaan kelompok daripada penghargaan individual.

Kegiatan kooperatif memberi

kesempatan kepada siswa untuk bekerja sendiri serta bekerja sama dengan orang lain. Keunggulan lain TPS adalah optimalisasi partisipasi siswa (Isjoni, 2007). Dengan metode klasikal memungkinkan hanya satu orang siswa maju dan membagikan hasilnya untuk seluruh kelas, tatapi pembelajaran kooperatif TPS memberi kesempatan sedikitnya delapan kali lebih banyak kepada setiap siswa untuk menunjukkan partisipasi mereka kepada orang lain (Lie, 2004).

Tabel 1. Sintaks Pembelajaran Kooperatif TPS

\begin{tabular}{|l|l|l|}
\hline No & \multicolumn{1}{|c|}{ Tingkah Laku Guru } & \multicolumn{1}{c|}{ Tingkah Laku Siswa } \\
\hline 1 & $\begin{array}{l}\text { Guru membagi siswa dalam kelompok 4-6 } \\
\text { orang siswa dan memberikan tugas } \\
\text { kepada semua kelompok }\end{array}$ & $\begin{array}{l}\text { Siswa terbagi dalam kelompok secara } \\
\text { heterogen }\end{array}$ \\
\hline 2 & $\begin{array}{l}\text { Guru memberi tugas kepada masing- } \\
\text { masing kelompok siswa }\end{array}$ & $\begin{array}{l}\text { Setiap siswa memikirkan dan } \\
\text { mengerjakan tugas tersebut sendiri }\end{array}$ \\
\hline 3 & $\begin{array}{l}\text { Guru meminta siswa untuk berdiskusi } \\
\text { dengan teman pasangannya dalam } \\
\text { kelompok dalam waktu 3-5 menit }\end{array}$ & $\begin{array}{l}\text { Siswa berpasangan dengan salah satu } \\
\text { rekan dalam kelompok dan berdiskusi } \\
\text { dengan pasangannya }\end{array}$ \\
\hline 4 & $\begin{array}{l}\text { Guru meminta setiap pasangan siswa } \\
\text { dalam kelompok untuk berkumpul dan } \\
\text { mendiskusikan hasil diskusi mereka }\end{array}$ & $\begin{array}{l}\text { Siswa kembali berkumpul dengan } \\
\text { anggota kelompoknya dan mereka } \\
\text { mempersiapkan presentasi materi di } \\
\text { depan kelas }\end{array}$ \\
\hline 5 & $\begin{array}{l}\text { Guru meminta perwakilan siswa untuk } \\
\text { membagikan hasil kerjanya di depan kelas }\end{array}$ & $\begin{array}{l}\text { Perwakilan kelompok siswa menyajikan } \\
\text { hasil kerjanya dan kelompok lain } \\
\text { mengklarifikasi }\end{array}$ \\
\hline 6 & $\begin{array}{l}\text { Guru memberi ulangan/ujian kepada } \\
\text { siswa }\end{array}$ & $\begin{array}{l}\text { Siswa menyelesaikan ulangan/ujian } \\
\text { mereka secara individual }\end{array}$ \\
\hline
\end{tabular}

Sumber : (Slavin. R, E. 1995. Cooperative learning: Theory, research, and practice; second edition. A Simon and Schuster)

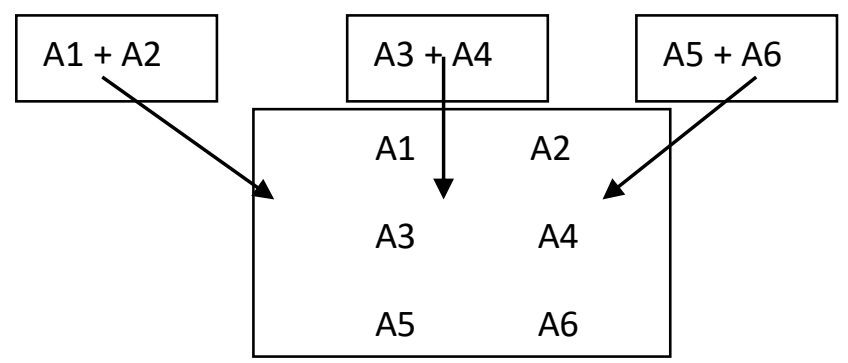


Gambar 1. Ilustrasi pembelajaran kooperatif tipe Think Pair Share

Menurut Isjoni (2007) bila jumlah anggota dalam satu kelompok semakin besar dapat mengakibatkan kurang efektif kerjasama antara para anggotanya. Hal yang perlu diperhatikan dalam pembelajaran kooperatif tipe jigsaw adalah guru harus memperhatikan skemata atau latar belakang pengalaman siswa dan membantu siswa mengaktifkan skematanya agar bahan pelajaran menjadi lebih bermakna. Selain itu, siswa bekerja dengan sesame siswa dalam suasana gotong-royong dan memiliki banyak kesempatan untuk mengolah informasi dan meningkatkan keterampilan berkomunikasi yang cocok.

Model pembelajaran kooperatif jigsaw membagi siswa dalam kelompok yang terdiri dari 4-5 orang siswa secara heterogen bekerja sama saling ketergantungan yang positif dan bertanggungjawab atas ketuntasan bagian materi pelajaran yang harus dipelajari dan menyampaikan materi tersebut kepada anggota kelompok yang lain (Arends, 1997). Selanjutnya jika tugas yang dikerjakan cukup sulit, siswa bisa membentuk kelompok para ahli. Siswa berkumpul dengan siswa lain yang mendapatkan bagian yang sama dari kelompok lain, kemudian bekerja sama mengerjakan bagian tersebut. Selanjutnya masing-masing siswa kembali ke kelompoknya sendiri membagikan apa yang telah dipelajarinya kepada rekan-rekan dalam kelompoknya (Lie, 2004). (2005) menjelaskan bahwa kecerdasan merupakan kemampuan individu untuk mengarahkan pikiran/tindakan, mampu mengubah arah tindakan bila diperlukan, dan mampu mengkritik diri sendiri. Sementara Weschler (1958) memandang intelegensi sebagai totalitas kemampuan individu untuk bertindak dengan tujuan tertentu, berpikir rasional serta menghadapi lingkungan dengan efektif (dalam Safaria, 2005).

Munurut Prof.Howard Gardner (dalam Linda Campbell, Bruce Campbell dan Dee Dickson, 2006:3), seorang ahli psikologi kognitif dari universitas Harvard meneliti tentang kecerdasan manusia. Ia menemukan bahwa setiap orang memiliki beberapa kecerdasan, tidak hanya satu kecerdasan yang disebut dengan multiple intelegences (kecerdasan ganda). Gardner (1999) menyebutkan ada Sembilan jenis kecerdasan yang dimiliki oleh setiap individu yaitu (1) kecerdasan ruang dan visual, (2) kecerdasan lisan atau bahasa, (3) kecerdasan matematis dan logis, (4) kecerdasan fisik dan gerak, (5) kecerdasan musik dan ritme, (6) kecerdasan interpersonal, (7) kecerdasan intrapersonal, (8) kecerdasan naturalis, dan (9) kecerdasan ekstensialis. Hal yang perlu diperhatikan adalah bahwa setiap orang memiliki kesembilan kecerdasan tersebut, setiap orang dapat mengembangkan kesembilan kecerdasan tadi sampai mencapai suatu tingkat yang memadai, kecerdasan bekerja satu sama lain secara kompleks, dan dalam tiap kecerdasan ada berbagai cara untuk menumbuhkan salah satu aspeknya.

(wwwl.bpkpenabur.or.id/kps-

jkt/berita/200103/kecerdasan-jamak.pc.diakses tanggal 20 februari 2010).

Johnson (1981) menambahkan bahwa "agar mampu memulai, mengembangkan, dan memelihara hubungan interpersonal serta komunikasi yang akrab, hangat, dan produktif dengan orang lain, anak perlu diajarkan sejumlah keteampilan dasar berkomunikasi, yaitu (1) anak harus mampu memiliki sikap saling memahami yang diperolehnya dari beberapa sub-kemampuan seperti sikap percaya, pembukaan diri, kesadaran diri, dan penerimaan diri, (2) anak harus mengkomunikasikan pikiran, dan perasaannya secara tepat, dan jelas (3) anak harus mampu menunjukkan sikap proposional, dan saling mendukung, dan (4) anak harus mampu memecahkan konflik dan bentuk-bentuk masalah antar pribadi dengan cara-cara yang konstruktif" (dalam safari, 2005). Kecerdasan interpersonal memiliki tiga dimensi utama, yaitu (1) social sensitivity, (2) social insight, dan (3) social communication. Sensitivitas sosial adalah kemampuan anak untuk mampu merasakan dan mengamati reaksi-reaksi atau perubaham orang lain yang ditunjukkannya baik secara verbal maupun nonverbal. Dasar dari social insight adalah berkembangnya kesadaran diri anak secara baik. Kesadaran diri yang berkembang ini akan membuat anak mampu memahami keadaan dirinya baik keadaan internal maupun eksternal seperti 
menyadari emosi-emosinya yang sedang muncul (internal) atau menyadari penampilan cara berpakaiannya sendiri, cara berbicaranya, dan intonasi suaranya (eksternal). Penguasaan keterampilan komunikasi sosial merupakan dalam menjalin dan membangun hubungan interpersonal yang sehat. Dalam proses menciptakan, membangun, dan mempertahankan relasi sosial, maka seseorang membutuhkan sarananya. Sarana yang digunakan adalah melaluirpsoses komunikasi yang mencakup baik komunikasi verbal, nonverbal maupun komunikasi melalui penampilan fisik. Keterampilan komunikasi yang harus dikuasai adalah keterampilan mendengarkan efektif, kemampuan berbicara efektif, keterampilan public speaking, dan keterampilan menulis secara efektif (Anderson dalam Safaria, 2005).

Ciri-ciri orang yang memiliki kecerdasan interpersonal yang bagus menurut Campbell, (Campbell dan Dickinson, 2006) antara lain (1) terikat dengan orang tua dan berinteraksi dengan orang lain, (2) membentuk dan menjaga hubungan sosial, (3) mengetahui dan menggunakan cara-cara yang beragam dalam berhubungan dengan orang lain, (4) merasakan perasaan, pikiran, motivasi, tingkah laku dan gaya hidup orang lain, (5) berpartisipasi dalam kegiatan kolaboratif dan menerima bermacam epran yang perlu dilaksanakan oleh semua individu dalam suatu usaha bersama, (6) mempengaruhi pendapat dan perbuatan orang lain, (7) memahami dan berkomunikasi secara efektif, baik dengan cara verbal maupun non-verbal, (8) menyesuaikan diri terhadap lingkungn dan kelompok yang berbeda dan juga umpan balik dari orng lain, (9) menerima perspektif yang bermacammacam dalam masaah sosial dan politik, (10) mempelajari keterampilan yang berhubungan dengan penengah sengketa, berhubungan dengan mengorganisasikan orang unuk bekerja sama ataupun bekerjasama dengan orang dari berbagai macam latar belakang dan usia, (11) tertarik pada karir yang berorientasi interpersonal seperti mengajar, pekerjaan social, konseling, manajemen atau politik, dan (12) membentuk proses social atau model yang baru.

Kecerdasan intrapersonal menunjukkan kemampuan seseorang untuk peka terhadap perasaan dirinya sendiri. Ia cenderung mampu untuk mengenali berbagai kekuatan maupun kelemahan yang ada pada dirinya sendiri. Peserta didik semacam ini senang melakukan intropeksi diri, mengoreksi kekurangan maupun kelemahannya, kemudian mencoba untuk memperbaiki diri. Beberapa di antaranya cenderung menyukai kesunyian dan kesendirian, merenung, dan berdialog dengan dirinya sendiri (Uno, 2009; 14). Menurut Lwyn (2008; 233) Kecerdasan intrapersonal adalah kecerdasan mengenai diri sendiri. Kecerdasan ini adalah kemampuan untuk memahami diri sendiri dan bertanggung jawab atas kehidupannya sendiri. Orang-orang yang berkercerdasan intrapersonal tinggi cenderung menjadi pemikir yang tercermin pada apa yang mereka lakukan dan terus menerus membuat penilaian diri. Mereka selalu bersentuhan dengan pemikiran, gagasan dan impian mereka dan mereka juga memiliki kemampuan untuk mengarahkan emosi mereka sendiri sedemikian rupa untuk memperkaya dan membimbing kehidupan mereka sendiri.

Berdasarkan rumusan masalah, kajian teoritis, dan kerangka berpikir yang telah dikemukakan sebelumnya, maka dapat diajukan hipotesis dalam penelitian ini sebagai berikut: (1) Terdapat perbedaan hasil belajar ekonomi antara siswa yang diajar dengan pembelajaran kooepratif Jigsaw dengan siswa yang diajar dengan pembelajaran kooperatif TPS; (2)Terdapat perbedaan hasil belajar ekonomi antara siswa yang memiliki kecerdasan interpersonal dengan siswa yang memiliki kecerdasan intrapersonal; dan (3) Terdapat interaksi antara model pembelajaran kooperatif dengan kecerdasan ganda yaitu kecerdasan interpersonal dan kecerdasan intrapersonal dalam mempengaruhi hasil belajar.

\section{METODE}

Penelitian ini dilaksanakan di SMA Negeri 1 Medang Deras Kabupaten Batu Bara, Populasi adalah totalitas semua nilai yang mungkin, hasil perhitungan atau pengukuran secara kuantitatif mengenai karakteristik tertentu dari semua anggota kumpulan yang lengkap dan jelas, yang ingin dipelajari sifatsifatnya (Sudjana dalam Helminaria, 2008 : 20). Populasi penelitian ini adalah seluruh siswa kelas X SMA Negeri 1 Medang Deras, yang terdiri dari tiga (4) kelas.

Teknik pengambilan sampel dalam penelitian ini dilakukan melalui pengambilan sampel secara acak rumpum (cluster random sampling), yakni semua individu dalam kelas sampel menjadi subjek penelitian. Dari sampel populasi akan dipilih 2 kelas sebagai sampel 
penelitian, kelas X-1 berjumlah 38 orang yang diberi perlakuan penerapan model pembelajaran kooperatif Jigsaw sebagai kelas eksperimen dan kelas X-2 berjumlah 41 orang yang diberi perlakuan penerapan model pembelajaran kooperatif TPS.
Metode yang akan digunakan dalam penelitian ini adalah metode eksperimen semu dengan desain faktorial $2 \times 2$. Variabel-variabel tersebut selanjutnya akan dimasukkan dalam desain penelitian seperti tabel 2 berikut :

Tabel 2. desain penelitian faktorial $2 \times 2$

\begin{tabular}{|l|l|l|}
\hline $\begin{array}{l}\text { Jenis } \\
\text { Kecerdasan }\end{array}$ & $\begin{array}{c}\text { Model pembelajaran } \\
\text { Kooperatif tipe Jigsaw } \\
\text { KX1) }\end{array}$ & $\begin{array}{c}\text { Model Pembelajaran } \\
\text { kooperatif tipe TPS } \\
\text { (X2) }\end{array}$ \\
\hline Interpersonal (Y1) & $\mathrm{X} 1 \mathrm{Y} 1$ & $\mathrm{X} 2 \mathrm{Y} 1$ \\
\hline Intrapersonal (Y2) & $\mathrm{X} 1 \mathrm{Y} 2$ & $\mathrm{X} 2 \mathrm{Y} 2$ \\
\hline
\end{tabular}

Keterangan :

X1Y1 : Hasil belajar ekonomi yang diajar dengan menggunakan model pembelajaran kooperatif tipe Jigsaw pada siswa yang memiliki kecerdasan interpersonal.

X2Y1 : Hasil belajar ekonomi siswa yang diajar dengan menggunakan model pembelajaran kooperatif tipe TPS pada siswa yang memiliki tingkat kecerdasan interpersonal.

X1Y2 : Hasil belajar ekonomi siswa yang diajar dengan menggunakan model pembelajaran kooperatif tipe Jigsaw pada siswa yang memiliki kecerdasan intrapersonal

X2Y2 : Hasil belajar ekonomi siswa yang diajar dengan menggunakan model pembelajaran kooperatif tipe TPS pada siswa yang memiliki kecerdasan intrapersonal

Teknik analisis data yang digunakan adalah teknik statistik deskriptif dan inferensial. Teknik statistik deskriptif digunakan untuk mendeskripsikan data antara lain : nilai rata-rata (mean), media, modus, standar deviasi (Sd) dan kecendrungan data. Teknik statistik inferensial digunakan untuk menguji hipotesis penelitian, dimana teknik inferensial yang akan digunakan adalah teknik analisis variasi dua jalur (disain faktorial $4 \times 2$ ) dengan taraf siginifikan 0,05. Sebelum antara dua jalur dilakukan, maka diadakan uji lanjut (post hoc test). Uji lanjut akan dilakukan dengan uji Tuckey jika jumlah sampel tiap sel sama besarnya, akan tetapi jika jumlah sampel tiap sel tidak sama (n tidak sama), maka akan digunakan uji Scheefe. Selanjutnya untuk keperluan pengujian hipotesis, dirumuskan hipotesis statistik sebagai berikut :

a) Hipotesis pertama

Ho : $\mu \times 1=\mu \times 2$

Ha : $\mu \times 1>\mu \times 2$

b) Hipotesis kedua

Ho : $\mu \mathrm{y} 1=\mu \mathrm{y} 2$

Ha : $\mu \mathrm{y} 1>\mu \mathrm{y} 2$

c) Hipotesis ketiga

Ho : $\mathrm{x}><\mathrm{y}=0$

Ha : $x><y \neq 0$

\section{HASIL DAN PEMBAHASAN}

Hasil

Sebelum melakukan pengujian hipotesis terlebih dahulu menghitung total skor dan rata-rata skor tiap kelompok perlakuan menurut tabel ANAVA, yang selanjutnya dapat digunakan sebagai dasar keputusan statistik untuk pengujian hipotesis, seperti pada Tabel 3 sebagai berikut: 
Tabel 3. Hasil Statistik Deskriptif

\begin{tabular}{|c|c|c|c|c|c|c|c|}
\hline \multirow{2}{*}{\multicolumn{2}{|c|}{ Variabel }} & \multicolumn{4}{|c|}{ Model Pembelajaran } & \multirow{2}{*}{\multicolumn{2}{|c|}{ Total }} \\
\hline & & & (A1) & & $(\mathrm{A} 2)$ & & \\
\hline \multirow{2}{*}{ 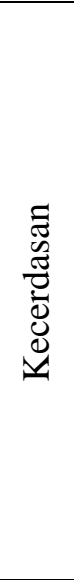 } & $\begin{array}{c}\text { Interpersonal } \\
\text { (B1) }\end{array}$ & $\begin{array}{l}\mathrm{n} \\
\bar{X} \\
\sum \mathrm{X} \\
\sum \mathrm{X}^{2} \\
\mathrm{~S}\end{array}$ & $\begin{array}{l}20 \\
34.20 \\
684 \\
23606 \\
3.35\end{array}$ & $\begin{array}{l}\mathrm{n} \\
\bar{X} \\
\sum \mathrm{X} \\
\sum \mathrm{X}^{2} \\
\mathrm{~S}\end{array}$ & $\begin{array}{l}19 \\
24.58 \\
449 \\
11821 \\
4.36\end{array}$ & $\begin{array}{l}\mathrm{n} \\
\bar{X} \\
\sum \mathrm{X} \\
\sum \mathrm{X}^{2} \\
\mathrm{~S}\end{array}$ & $\begin{array}{l}39 \\
29.51 \\
1151 \\
35427 \\
619\end{array}$ \\
\hline & $\begin{array}{c}\text { Intrapersonal } \\
\text { (B2) }\end{array}$ & $\begin{array}{l}\mathrm{n} \\
\bar{X} \\
\sum \mathrm{X} \\
\sum \mathrm{X}^{2} \\
\mathrm{~S}\end{array}$ & $\begin{array}{l}18 \\
22.72 \\
409 \\
9551 \\
3.89\end{array}$ & $\begin{array}{l}\mathrm{n} \\
\bar{X} \\
\sum \mathrm{X} \\
\sum \mathrm{X}^{2} \\
\mathrm{~S}\end{array}$ & $\begin{array}{l}22 \\
27.68 \\
609 \\
17417 \\
5.16\end{array}$ & $\begin{array}{l}\mathrm{n} \\
\bar{X} \\
\sum \mathrm{X} \\
\sum \mathrm{X}^{2} \\
\mathrm{~S}\end{array}$ & $\begin{array}{l}40 \\
25.45 \\
1018 \\
26968 \\
5.21\end{array}$ \\
\hline & Total & $\begin{array}{l}\mathrm{n} \\
\bar{X} \\
\sum \mathrm{X} \\
\sum \mathrm{X}^{2} \\
\mathrm{~S}\end{array}$ & $\begin{array}{l}38 \\
28.76 \\
1093 \\
33157 \\
6.82\end{array}$ & $\begin{array}{l}\mathrm{n} \\
\bar{X} \\
\sum \mathrm{X} \\
\sum \mathrm{X}^{2} \\
\mathrm{~S}\end{array}$ & $\begin{array}{l}41 \\
26.24 \\
1076 \\
29238 \\
5.00\end{array}$ & $\begin{array}{l}\mathrm{n} \\
\bar{X} \\
\sum \mathrm{X} \\
\sum \mathrm{X}^{2} \\
\mathrm{~S}\end{array}$ & $\begin{array}{l}79 \\
27.48 \\
2169.00 \\
62395 \\
11.41\end{array}$ \\
\hline
\end{tabular}

bawah ini.

Secara keseluruhan hasil uji anava untuk pengujian hipotesis dapat dilihat pada Tabel 4 di Tabel 4. Rangkuman Hasil Anava Secara Keseluruhan Terhadap Hasil belajar Ekonomi

\begin{tabular}{|l|c|c|c|c|c|}
\hline \multicolumn{1}{|c|}{ Sumber variasi } & $\mathrm{dk}$ & $\mathrm{JK}$ & $\mathrm{RJK}$ & $\mathrm{F}_{\text {hitung }}$ & $\mathrm{F}_{\text {tabel }}(\alpha=0.05)$ \\
\hline Model Pembelajaran & 1 & 125.47 & 125.47 & 4.19 & 3.99 \\
\hline Kecerdasan & 1 & 325.16 & 325.16 & 10.91 & 3.99 \\
\hline Interaksi & 1 & 152.47 & 152.47 & 5.12 & 3.99 \\
\hline Galat Total & 75 & 2240.0 & 29.87 & & \\
\hline \multicolumn{2}{|c|}{ T8 } & & & & \\
\hline
\end{tabular}

Perbedaan Hasil belajar Ekonomi Siswa Yang Menggunakan Model Pembelajaran Kooperatif Tipe Jigsaw dan Model Pembelajaran Kooperatif Tipe TPS

Adapun hipotesis statistik yang diuji adalah :

Ho : $\mu \mathrm{A}_{1}=\mu \mathrm{A}_{2}$

$\mathrm{Ha}: \mu \mathrm{A}_{1}>\mu \mathrm{A}_{2}$

Berdasarkan hasil pengujian hipotesis pada Tabel 4.16. di atas, maka diperoleh hasil perhitungan data kelompok model pembelajaran, dimana $F_{\text {hitung }}=4.19$ sementara nilai kritik $\mathrm{F}_{\text {tabel }}$ dengan $\mathrm{dk}=(1,75)$ dan $\alpha=$ 0.05 adalah sebesar 3.99. Hasil ini menunjukkan bahwa $F_{\text {hitung }}=4.19>F_{\text {tabel }}=3.99$ sehingga Hipotesis Nol (Ho) ditolak, hal ini berarti menerima Hipotesis alternatif $(\mathrm{Ha})$. Dengan demikian hipotesis penelitian yang menyatakan bahwa hasil belajar Ekonomi siswa yang menggunakan Model Pembelajaran
Kooperatif Tipe Jigsaw lebih tinggi dibandingkan siswa yang dibelajarkan dengan model pembelajaran kooperatif tipe TPS teruji kebenarannya.

Perbedaan Hasil belajar Ekonomi Siswa Yang Memiliki Kecerdasan interpersonal dan Kecerdasan intrapersonal

Adapun hipotesis statistik yang diuji adalah :

Ho : $\mu \mathrm{B}_{1}=\mu \mathrm{B}_{2}$

$\mathrm{Ha}: \mu \mathrm{B}_{1}>\mu \mathrm{B}_{2}$

Berdasarkan hasil pengujian hipotesis pada Tabel 4.16. di atas diperoleh hasil perhitungan data kecerdasan, dimana $\mathrm{F}_{\text {hitung }}=$ 10.91 dan nilai kritik $\mathrm{F}_{\text {tabel }}$ dengan $\mathrm{dk}=(1,75)$ dan $\alpha=0.05$ adalah 3.99. Hasil ini menunjukkan bahwa $\mathrm{F}_{\text {hitung }}=10.91>\mathrm{F}_{\text {tabel. }}=$ 3.99. Sehingga Hipotesis Nol (Ho) ditolak dan Hipotesis alternatif (Ha) diterima, dengan demikian hipotesis penelitian yang menyatakan 
bahwa hasil belajar Ekonomi siswa yang memiliki Kecerdasan interpersonal lebih tinggi dibandingkan yang memiliki kecerdasan intrapersonal teruji kebenarannya.

Interaksi Model Pembelajaran dan Kecerdasan diri Siswa Dalam Mempengaruhi Hasil belajar Ekonomi adalah :

Adapun hipotesis statistik yang diuji

Ho : $\mathrm{A}><\mathrm{B}=0$

$\mathrm{Ha}: \mathrm{A}><\mathrm{B} \neq 0$

Berdasarkan hasil pengujian hipotesis pada Tabel 4.16 di atas, maka diperoleh hasil perhitungan interaksi model pembelajran dan kecerdasan, di mana $F_{\text {hitung }}=5.10$ sementara nilai kritik $\mathrm{F}_{\text {tabel }}$ dengan $\mathrm{dk}=(1.75)$ dan $\alpha=$ 0.05 adalah sebesar 3.99. Hasil ini menunjukkan bahwa $F_{\text {hitung }}=5.10>F_{\text {tabel }}=3.99$ sehingga Hipotesis Nol (Ho) ditolak dan
Hipotesis alternatif (Ha) diterima, dengan demikian hipotesis penelitian yang menyatakan bahwa terdapat interaksi antara model pembelajaran dan kecerdasan dalam mempengaruhi hasil belajar ekonomi teruji kebenarannya.

Karena ada interaksi antara model pembelajaran dan kecerdasan dalam mempengaruhi hasil belajar Ekonomi, maka perlu dilakukan uji lanjutan (post hoc test), untuk mengetahui rata-rata hasil belajar Ekonomi sampel mana yang berbeda. Untuk melihat bentuk interaksi antara model pembelajaran dan kecerdasan dalam mempengaruhi hasil belajar ekonomi, dilakukan uji lanjut dengan menggunakan uji Scheffe. Ringkasan hasil uji Scheffe dapat dilihat pada Tabel 5 berikut:

Tabel 5. Ringkasan Hasil Perhitungan Uji Scheffe'

\begin{tabular}{|c|c|c|c|c|}
\hline No & \multicolumn{2}{|c|}{ Hipotesis Statistik } & \multirow{2}{*}{ F $_{\text {hitung }}$} & $\mathbf{F}_{\text {tabel }}$ \\
\cline { 3 - 5 } & & $\boldsymbol{\alpha}=\mathbf{5 \%}$ \\
\hline 1 & $\mathrm{H}_{\mathrm{o}}: \mu \mathrm{A}_{1} \mathrm{~B}_{1}=\mu \mathrm{A}_{2} \mathrm{~B}_{1}$ & $\mathrm{H}_{\mathrm{a}}: \mu \mathrm{A}_{1} \mathrm{~B}_{1}>\mu \mathrm{A}_{2} \mathrm{~B}_{1}$ & 5.49 & 2.75 \\
\hline 2 & $\mathrm{H}_{\mathrm{o}}: \mu \mathrm{A}_{1} \mathrm{~B}_{1}=\mu \mathrm{A}_{2} \mathrm{~B}_{2}$ & $\mathrm{H}_{\mathrm{a}}: \mu \mathrm{A}_{1} \mathrm{~B}_{1}>\mu \mathrm{A}_{2} \mathrm{~B}_{2}$ & 3.86 & 2.75 \\
\hline 3 & $\mathrm{H}_{\mathrm{o}}: \mu \mathrm{A}_{1} \mathrm{~B}_{1}=\mu \mathrm{A}_{1} \mathrm{~B}_{2}$ & $\mathrm{H}_{\mathrm{a}}: \mu \mathrm{A}_{1} \mathrm{~B}_{1}>\mu \mathrm{A}_{1} \mathrm{~B}_{2}$ & 6.46 & 2.75 \\
\hline 4 & $\mathrm{H}_{\mathrm{o}}: \mu \mathrm{A}_{2} \mathrm{~B}_{1}=\mu \mathrm{A}_{2} \mathrm{~B}_{2}$ & $\mathrm{H}_{\mathrm{a}}: \mu \mathrm{A}_{2} \mathrm{~B}_{1}>\mu \mathrm{A}_{2} \mathrm{~B}_{2}$ & 1.81 & 2.75 \\
\hline 5 & $\mathrm{H}_{\mathrm{o}}: \mu \mathrm{A}_{1} \mathrm{~B}_{2}=\mu \mathrm{A}_{2} \mathrm{~B}_{2}$ & $\mathrm{H}_{\mathrm{a}}: \mu \mathrm{A}_{1} \mathrm{~B}_{2}>\mu \mathrm{A}_{2} \mathrm{~B}_{2}$ & 2.85 & 2.75 \\
\hline 6 & $\mathrm{H}_{\mathrm{o}}: \mu \mathrm{A}_{1} \mathrm{~B}_{2}=\mu \mathrm{A}_{2} \mathrm{~B}_{1}$ & $\mathrm{H}_{\mathrm{a}}: \mu \mathrm{A}_{1} \mathrm{~B}_{2}>\mu \mathrm{A}_{2} \mathrm{~B}_{1}$ & 1.03 & 2.75 \\
\hline
\end{tabular}

Selanjutnya adanya interaksi antara variabel model pembelajaran dan kecerdasan terhadap hasil belajar Ekonomi siswa, maka perlu diberikan gambaran grafik estimasi yang menunjukkan adanya interaksi tersebut. Grafik interaksi ditunjukkan oleh gambar 2. berikut:

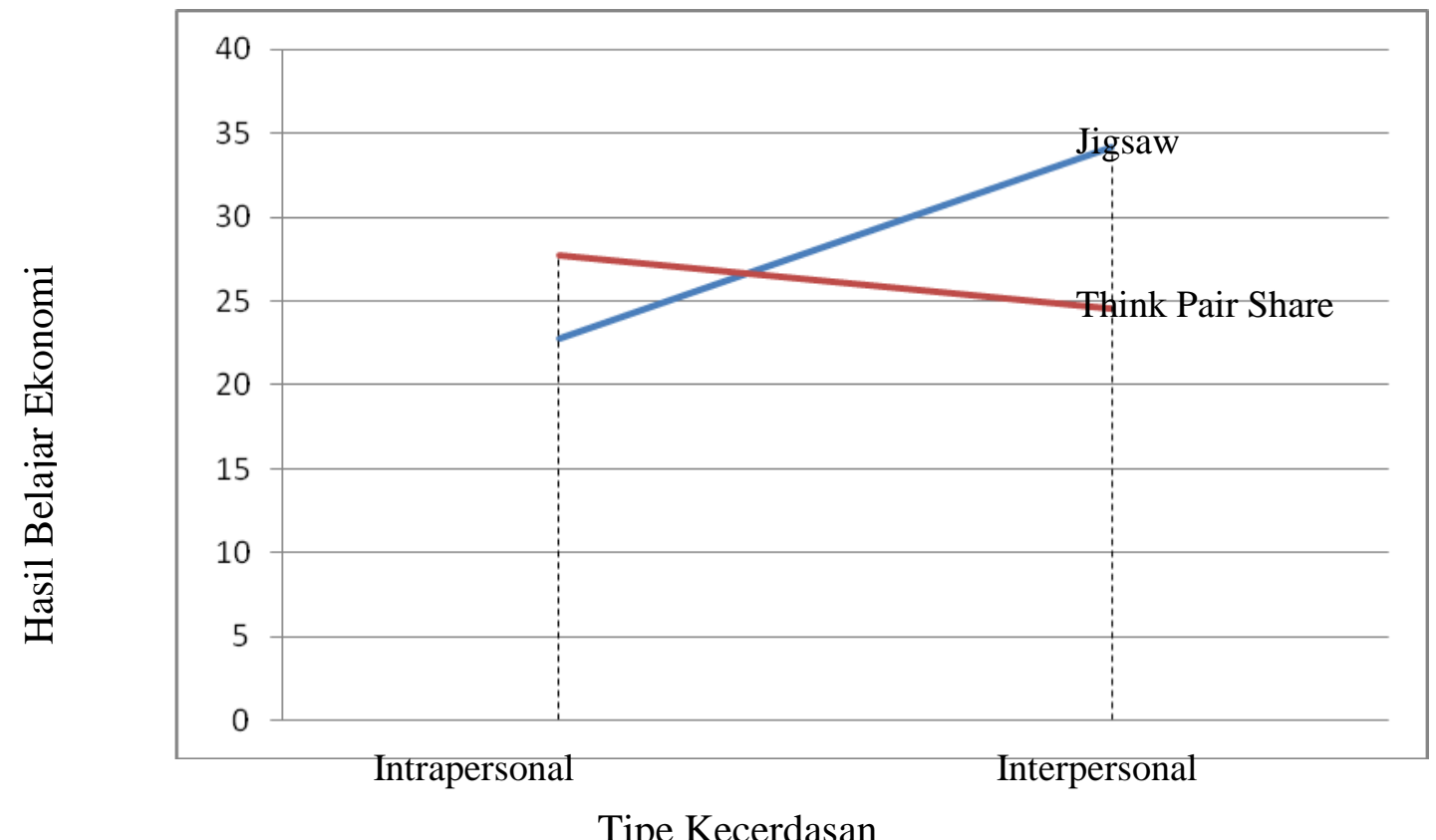

Gambar 2. Model Interaksi Model rembelajaran dan Kecerdasan Terhadap Hasil belajar Ekonomi 


\section{Pembahasan}

Pembelajaran kooperatif Jigsaw memberikan dampak positif terhadap kegiatan belajar mengajar yang dilakukan oleh guru, karena dapat meningkatkan minat siswa dalam mengikuti pembelajaran berikutnya. Selain itu, pembelajaran kooperatif Jigsaw merupakan lingkungan belajar yang menghendaki siswa belajar bersama dalam kelompok kecil yang heterogen untuk menyelesaikan tugas-tugas pembelajaran. Siswa berinteraksi mempelajari materi yang diberikan kepadanya dan mempertanggungjawabkan hasil kepada anggota kelompoknya. Jadi siswa terlatih berani melakukan interaksi dengan teman-temannya.

Siswa dalam pembelajaran kooperatif TPS belajar dengan teman sekelompoknya. Mungkin saja akan terjadi perselisihan yang muncul diantara siswa atau ada siswa yang kurang aktif selama kegiatan diskusi, bahkan mungkin juga terdapat siswa yang sulit diajak bekerjasama untuk menyelesaikan tugas-tugas belajar mereka, sehingga dalam menyelesaikan tugas akan lebih banyak dilakukan oleh siswa yang memiliki kemampuan belajar lebih tinggi sedangkan siswa yang memiliki kemampuan belajar rendah sulit untuk membantu mereka. Akibatnya siswa merasa dirugikan dengan demikian akan mempengaruhi hasil belajar mereka.

Siswa yang memiliki kecerdasan interpersonal suka berinteraksi dengan teman, guru atau dengan orang lain. Dengan kemampuan yang dimiliki dalam mempengaruhi teman belajarnya, tampak bahwa siswa yang memiliki kecerdasan interpersonal lebih menonjol dalam kerja kelompok, atau kegiatan-kegiatan kelompok seperti bermusyawarah untuk mencapai kesepakatan. Bagi siswa yang memiliki tingkat kecerdasan interpersonal tinggi dapat dilihat dari kemampuan mereka dalam berkomunikasi, membina hubungan sosial maupun mengadakan interaksi dengan teman-temannya, misalnya pada saat tanya-jawab atau mempresentasikan makalah dan tugas belajar lainnya.

Siswa yang memiliki kecerdasan interpersonal tinggi tentunya lebih mudah menyelesaikan tugas belajar mereka bila dibandingkan dengan siswa yang memiliki kecerdasan interpersonal rendah. Karena siswa yang memiliki kecerdasan interpersonal tinggi lebih mampu untuk memahami situasi atau suasana hati temannya, apakah dalam keadaan baik atau tidak. Sedangkan siswa yang memiliki kecerdasan interpersonal rendah akan banyak menemukan kesulitan dalam membina hubungan sosial pada lingkungan belajarnya. Dengan demikian siswa yang memiliki kecerdasan interpersonal rendah sulit untuk menyampaikan maksudnya, sulit membaca ekspresi wajah temannya.

Siswa yang memiliki kecerdasan intrapersonal yang tinggi cenderung bertanggung jawab dan menjadi pemilik kehidupan mereka sendiri. Mereka merasa bertanggungjawab atas akibat dari apa yang mereka hasilkan. Ketika kegiatan kerja kelompok ada hal-hal yang tidak beres atau terdapat kesalahan, maka mereka cepat mengambil tanggung jawab. Dengan melakukan hal tersebut, maka mereka mampu mengubah situasi diskusi dari yang tidak kondusif menjadi kondusif. Siswa tersebut selalu merasa bahwa mereka mampu melakukannya. Sebaliknya, siswa dengan kecerdasan intrapersonal rendah umumnya cenderung mengambil peran sebagai korban. Apabila ada kesalahan atau sesuatu yang tidak beres, maka mereka menyalahkan setiap orang kecuali diri mereka sendiri. Yang salah selalu orang lain karena mereka tidak mau bertanggung jawab. Ketika ada pertanyaan dari kelompok lain yang ditujukan kepada mereka, dan anggota yang lain tidak dapat menjawab dan tidak mampu bertanggungjawab, maka siswa tersebut akan menyalahkan mereka tentang kesalahan tersebut. Dan akhirnya akan mempengaruhi anggota lainnya, dan siswa yang lain akan merasa bahwa hasil diskusinya tersebut sia-sia yang akhirnya akan mempengaruhi hasil belajar. Dan akibatnya bagi siswa yang memiliki kecerdasan intrapersonal rendah adalah akan dijauhi oleh siswa yang lainnya karena tidak mampu bekerjasama dengan yang lainnya. Dan jika ada tugas yang baru yang diberikan oleh guru maka mereka akan menolak digabungkan dengan siswa tersebut.

Interaksi dapat terjadi antara dua variabel bebas, yaitu jika terjadi pengaruh yang berbeda dari salah satu variable di antara kedua variable itu pada tingkatan berbeda dari variabel lainnya. Variabel bebas dalam penelitian ini model pembelajaran kooperatif tipe TPS dan model pembelajaran kooperatif tipe Jigsaw. Variabel moderator dalam penelitian ini adalah kecerdasan ganda. Jika terjadi interaksi, maka 
pengaruh model pembelajaran terhadap kecerdasan interpersonal dan kecerdasan intrapersonal dengan perlakuan yang sama terhadap kedua kecerdasan tersebut.

Dalam pembelajaran kooperatif Jigsaw bagi siswa yang memiliki kecerdasan interpersonal, mereka akan merasa senang bekerjasama dengan siswa yang lain yang memiliki kemampuan rendah. Akan tetapi terjadi pergantian teman dalam kelompok diskusi pada tim ahli, dalam diskusi tim ahli, siswa yang memiliki kemampuan tinggi akan berkumpul dan membahas materi pelajaran yang sama, kemudian mereka akan kembali mengajarkan materi tersebut kepada teman kelompok asalnya masing-masing. Dengan pola seperti ini maka perselisihan atau kejenuhan siswa yang memiliki kecerdasan interpersonal dapat sedikit diatasi, namun berbeda dengan siswa dalam kelompok asal, meskipun mereka juga melakukan diskusi tetapi mereka memiliki beban mental, dikarenakan ketidakmampuannya terlihat jelas dengan pembagian kelompok asal dan kelompok ahli.

Pada saat penelitian, siswa diajarkan dengan dua model pembelajaran kooperatif yaitu kooperatif jigsaw dan kooperatif TPS, kemudian dengan dua model pembelajaran tersebut diajarkan kepada siswa yang memiliki kecerdasan interpersonal dan intrapersonal. Selanjutnya siswa akan memilih model pembelajaran kooperatif yang mana yang cocok dengan kecerdasan yang dimilikinya. Hal ini menimbulkan interaksi antara model pembelajaran kooperatif dengan kecerdsaan ganda dalam mempengaruhi hasil belajar ekonomi siswa tersebut.

Model pembelajaran kooperatif perlu dipahami oleh guru sebelum diajarkan pada siswa, tujuannya agar guru dapat menempatkan model pembelajaran yang mana yang paling tepat untuk materi pelajaran yang akan diajarkannya. Pada model pembelajaran kooperatif, guru yang akan membentuk kelompok pada siswa harus menanamkan sikap dan jiwa demokrasi sehingga terdapat keterbukaan terhadap siswa dan guru sewaktu proses pembelajaran.

Model pembelajaran kooperatif yang digunakan pada peneltian ini adalah model pembelajaran kooperatif jigsaw dan TPS, keduanya memiliki perbedaan yang signifikan. Pada hakikatnya model pembelajaran jigsaw merupakan model pembelajaran yang mendorong para siswa untuk berinteraksi dan saling membantu dalam menguasai materi pelajaran yang diberikan oleh guru kepada siswa, dengan adanya kelompok asal dan kelompok ahli. Sedangkan model pembelajaran kooperatif TPS adalah diskusi kelompok yang berpasangan, dan menjelaskan materi yang didiskusikan pada pasangannya masing-masing.

Siswa yang memiliki kecerdasan interpersonal mampu berkomunikasi dengan baik dengan siswa yang lain, mampu memecahkan konflik dan bentuk masalah antar pribadi dengan cara yang konstruktif, dan mampu memahami realitas di sekelilingnya atas pembandingan sosial untuk memperoleh pemahaman akan dunia sekelilingnya, oleh karena itu model pembelajaran kooperatif tipe jigsaw lebih tepat digunakan untuk siswa yang memiliki kecerdasan interpersonal. Sementara siswa yang memiliki kecerdasan intrapersonal tidak mampu berkomunikasi dengan baik dengan siswa lain, mereka hanya memahami dirinya sendiri dan lebih cenderung pemalu dan menyendiri sehingga model pembelajaran kooperatif tipe jigsaw kurang tepat untuk diajar kepada siswa yang memiliki kecerdasan intrapersonal.

Model pembelajaran tipe TPS memiliki prosedur yang eksplisit dalam memberi waktu kepada siswa lebih banyak untuk berpikir, menjawab dan saling membantu satu sama lain. Dalam proses pembelajaran dibutuhkan proses yang melibatkan niat untuk bekerja sama dengan anggota lain. Sehingga untuk melaksanakan kerjasama yang baik dengan kelompok lain dibutuhkan sikap dan perilaku yang terbuka menerima siswa lain, sikap ini dapat ditunjukkan oleh siswa yang memiliki kecerdasan interpersonal. Sedangkan siswa yang memiliki kecerdasan intrapersonal sedikit sulit untuk melakukannya. Sejalan dengan hal ini, hasil temuan penelitian menunjukkan hasil belajar ekonomi siswa yang memiliki kecerdasan interpersonal jika diajar dengan menggunakan model pembelajaran kooperatif tipe TPS lebih baik dibanding siswa yang memiliki kecerdasan intrapersonal.

Apabila dikaitkan dengan kecerdasan intrapersonal yang dimiliki oleh siswa maka model pembelajaran kooperatif tipe jigsaw ini memang sangat sulit diterapkan kepada siswa dibanding model pembelajaran kooperatif tipe TPS, akan tetapi sangat baik digunakan untuk siswa yang memiliki kecerdasan intrapersonal karena dapat mengajarkan siswa bekerja sama dengan siswa lain, dan bagaimana menerima 
perbedaam yang dimiliki setiap siswa. Dan hasil penelitian ini menunjukkan hasil belajar siswa yang memiliki kecerdasan intrapersonal jika diajar dengan menggunakan model pembelajaran kooperatif tipe jigsaw lebih baik dibanding siswa yang memiliki kecerdasan interpersonal dengan tipe TPS.

\section{PENUTUP}

Dari uraian hasil penelitian dapat diambil beberapa simpulan, yaitu:

1. Hasil belajar Ekonomi $(\bar{x}=28.76)$ siswa yang diajarkan dengan pembelajaran kooperatif jigsaw lebih tinggi dari hasil belajar Ekonomi ( $\bar{x}=26.20)$ siswa yang diajarkan dengan pembēlajaran kooperatif TPS, sehingga tidak terdapat perbedaan yang signifikan.

2. Hasil belajar Ekonomi $(\bar{x}=29.58)$ siswa yang memiliki kecerdasan Interpersonal lebih tinggi dari hasil belajar Ekonomi $(\bar{x}=$ 25.4) siswa yang memiliki kecerdasan Intrapersonal.

3. Terdapat Interaksi antara model pembelajaran kooperatif dengan kecerdasan ganda (interpersonal dan intrapersonal) dalam mempengaruhi hasil belajar Ekonomi yang dibuktikan dari hasil tabel ANAVA, di mana $\mathrm{F}_{\text {hitung }}=5.10$ sementara nilai kritik $\mathrm{F}_{\text {tabel }}$ dengan $\mathrm{dk}=(1.75)$ dan $\alpha=0.05$ adalah sebesar 3.99. Hasil ini menunjukkan bahwa $\mathrm{F}_{\text {hitung }}=5.10>\mathrm{F}_{\text {tabel }}=3.99$.

Dari beberapa penjelasan diatas dapat ditarik kesimpulan yang mendasar bahwa pada pembelajaran dengan menggunakan model pembelajaran Kooperatif tipe Jigsaw lebih cenderung kepada penggunaan kecerdasan Interpersonal yang dibuktikan pada penjelasan diatas dengan perbedaan yang sangat signifikan pada hasil belajar Ekonomi siswa. Sedangkan pada pembelajaran dengan menggunakan model pembelajaran Kooperatif tipe TPS lebih cenderung kepada penggunaan kecerdasan Intrapersonal walaupun tidak memiliki perbedaan yang sangat signifikan pada hasil belajar Ekonomi siswa.

\section{DAFTAR PUSTAKA}

Arikunto, S. (2002). Prosedur Penelitian. Jakarta: Rineka cipta. (2007). Manajemen Penelitian. Jakarta : Rineka cipta (2008). Dasar-Dasar Evaluasi Pendidikan. Jakarta : Bumi Aksara.
Budiningsih, C Asri. 2004. Belajar dan Pembelajaran. Jakarta: PT.Rineka Cipta

Campbell, D.T. Stanley, J.C. (1966) Experimental and Quasy-Experimental Design For Research. USA: Rand Mc Nally \& Company Chicago

Dimyati dan Mudjiono. (2006). Belajar dan Pembelajaran. Jakarta: Rineka Cipta

Halimah, Siti. 2008. Strategi Pembelajaran. Medan. Citapustaka Media Perintis

Hutabara, Helmenaria. Pengaruh Strategi Pembelajaran dan Minat Belajar terhadap hasil belajar kebutuhan dasar manusia II mahasiswa jurusan keperawatan politeknik kesehatan Medan. 2008. Medan: Tesis Program Studi Teknologi Pendidikan UNIMED.

Isjoni. 2009. Cooperative Learning. Bandung: Alfabeta.

Joice dan Weil. 1996. Models of teaching : fifth edition. A.Simon and Schuster

Khairudin. Kecerdasan interpersonal. http://khairudicyber.blog.friendster.com/ kecerdasan/kecerdasan-intrapersonal/, diakses tanggal 20 Maret 2010).

Kunandar. (2007). Guru profesional Implementasi Kurikulum Tingkat Satuan Pendidikan dan Persiapan Menghadapi Sertifikasi Guru. Jakarta : Raja Grafindo Persada

Lie, A. (2004). Cooperative learning : Mempraktikkan cooperative learning di ruang-ruang kelas. Jakarta: Grasindo

Lwin, May, Khoo Adam, dkk. 2008. Cara Mengembangkan Berbagai Komponen Kecerdasan. Yogyakarta: PT. Macanan Jaya Cemerlang.

Nathael dan Adikara. (2008). Kecerdasan jamak : mengenali, memahami dan mengembangkannya.(http://wwwl.bpkpe nabur.or.id/kpsjkt/berita/200103/kecerdasan-jamak.pc diakses 20 Februari 2008.

Prayudi,Yusuf.kecerdasan.http://prayudi.wordpr ess.com/2007/05/05/kecerdasan/, diakses tanggal 10 april 2010).

Purwanto, N.(2007). Psikologi pendidikan. Bandung : Posdakarya

Rahmah, Yenice. Pengaruh Model Pembelajaran dan Kemampuan Berpikir Kritis terhadap hasil belajar IPA siswa kelas III sekolah dasar (SD) kota langsa. 2008. Medan: Tesis Program Studi Teknologi Pendidikan UNIMED. 
Rejeki, S. (2001). Meningkatkan mutu minat belajar biologi melalu model pembelajaran teams games tournament. Buletin pelangi pendidikan. Vol 4 (1): 13.

Romizwoski, A.J. (1981). Instructional Design System, Decision Making in Course Planning and Curriculum Design. London : Kogan.

Sabri, Ahmad. 2007. Strategi Belajar Mengajar. Padang: Quantum Teaching.

Samuelson, Paul A. \& Nordhaus, Willam D. (1985). Economics, New York: McGrawHill Book Company.

Sanjaya, Wina. 2008. Strategi Pembelajaran. Jakarta: Prenada Media Group.

Safaria, T. (2005). Interpersonal intelligence : metode pengembangan kecerdasan interpersonal anak. Yogyakarta: Amara books.

Siswandi. (2005). Pengaruh pembelajaran kooperatif tipe Jigsaw terhadap hasil belajar siswa pada materi pokok pengelolaan lingkungan di SMP. Tesis. Perpustakaan UPI.

Slavin, Robert E. !995). Cooperative Learning: Teory, Research and Practice (2ed). Boston: ALlyn and Bacon Piblicher

Solihatin, Etin, Raharjo. 2008. Cooperative Learning, Analisis Model Pembelajarn IPS. Jakarta: Bumi Aksara.

Syafaruddin dan Nasution, I. (2005) Manajemen Pembelajaran. Jakarta. Quantum teaching.

Uno, Hamzah B. 2008. Perencanaan Pembelajaran. Jakarta : PT. Bumi Aksara. . 2008. Teori Motivasi dan Pengukurannya. Jakarta: PT. Bumi Aksara. . 2009. Mengelola Kecerdasan dalam Pembelajaran. Jakarta : Bumi Aksara 